\title{
Archipelago Insights as Efforts to Establish National Geostrategic Resilience: A Literature Review
}

\author{
Khansa 'Avi ${ }^{1}$,Hemas Kumala Dewi ${ }^{2}$, Moses Glorino R. P. ${ }^{2}$ \\ ${ }^{1}$ Faculty of Economic and Business, Universitas Airlangga, Surabaya, Indonesia \\ ${ }^{2}$ Faculty of Humanities, Universitas Airlangga, Surabaya, Indonesia
}

\section{Corresponding Author:}

hemas.kumala.dewi-2020@fib.unair.ac.id

\begin{abstract}
Background: Indonesia is one of the multicultural countries in the world. The diversity that exists in Indonesia is reflected in differences in race, ethnicity, culture, and religion. It is not surprising that Indonesia will face the threat of national disintegration due to differences. Therefore, Indonesia needs a concept in fostering diversity to create national resilience. Purpose: This study aims to explore how the role of archipelago insights in shaping national geostrategy resilience. Method: The method used in this research is literature review. The search for journals was carried out using the google scholar database with the keywords "archipelago insight" and "geostrategy" and "national resilience". Feasibility studies are assessed based on title, abstract, full text, and research methodology. Data analysis using narrative analysis based on research findings. Result: insight into the archipelago can be used as a basis in shaping a national geostrategy. The perspective in the concept of archipelago insight by fostering the diversity in Indonesia can create unity and integrity to form national geostrategic resilience. Conclusion: The concepts that exist in the archipelago perspective and national geostrategy can foster the diversity that exists in Indonesia. The creation of existing unity and integrity, understanding the perception of seeing differences, is not a threat to realizing national resilience in the Indonesian nation.
\end{abstract}

Keywords: Geostrategy, National Resilience, Archipelago Insights.

\section{INTRODUCTION}

Indonesia is part of one of the largest multicultural countries in the world. Multicultural culture in Indonesia can be caused by the separation from one island to another, so that each community group is unique in its socio-cultural life. The geographic condition of the Indonesian territory, which consists of more than 17 thousand islands with a length of 300 
miles from east to west and more than 1000 miles north to south, can also be a factor in the multicultural situation of the nation in Indonesia (2). This diversity is reflected in people's lives such as the diversity of religions, races, ethnicities, customs, and many more (3). A high tolerance attitude needs to be possessed and animated by every Indonesian people to maintain unity and integrity in the life of a multicultural society in Indonesia (4).

Indonesia has a high threat of disintegration, both from external and internal factors. Sometimes the most frequent threats caused by internal threats such as corruption, conflicts between certain ethnic groups, radicalism, identity crises, natural disasters, and many more (5). If this threat is not taken seriously, conflicts will arise in Indonesian society that can threaten national integration (6).

The insight of the archipelago is one of the important factors in national integrity. The archipelago insight consists of several elements, namely, having one sense of society with one another, having the same national understanding, and having a national spirit in fighting for the nation's name (7). The insight of the archipelago is the basis for carrying out a state life that includes all aspects of the life of Indonesian society. In addition, the archipelago insight can be a view in realizing national resilience. Therefore, the insight of the archipelago is one of the factors in advancing development (8).

Geostrategy is a form of national resilience. all Indonesian people are obliged to understand the geostrategic concept to realize unity and integrity in the Republic of Indonesia (9). The role of geostrategy in social life is to become the basis for determining national policies and goals in utilizing Indonesian territory (10). For this reason, the archipelago insight is needed in building a national geostrategy because the concepts contained in the archipelago insight are the key to the realization of national geostrategic resilience (11).

Based on the background of the problems that have been presented, the researchers determined the following research questions: How is the archipelago's insight in shaping national geostrategic resilience? Thus, the research explores how the relationship between the role of archipelago insights in shaping national geostrategic resilience.

\section{METHOD}

This study used a method literature review. Literature searches were carried out on the database electronic Google Scholar using the keywords "archipelago insight" and 
"geostrategy" and "national resilience". The data obtained are then processed using descriptive analysis by describing the facts and theories from journals and other references, then analyzing the data to form a conclusion.

Based on the results of literature search on five databases, there are 154 articles. The search results were then checked for duplication, found that there were 35 similar articles, so they were excluded, and the left the remaining 119 articles. The researcher then conducted a filtering based on the title $(n=119)$, abstract $(n=45)$, and full text $(n=10)$ according to the literature review theme. The assessment was carried out based on the eligibility of the inclusion and exclusion criteria and obtained eleven articles used in the literature review.

\section{RESULT}

Based on the analysis in table 1, it is concluded that the insight of the archipelago can increase one's sense of homeland love (15). The values contained in the insight of the archipelago can realize national integration. Socialization of the archipelago's insight needs to be done to the public so that people are aware of their role in maintaining unity to realize national resilience (19). In addition, Pancasila can also be the key in solving every problem facing Indonesia (20).

Several external and internal factors can also hinder the application of the archipelago's insight to the community. Examples of these factors are the lack of public participation, minimal budgets, and the lack of implementation of the archipelago's insight into education. All of these factors can hinder the implementation of the archipelago insight, resulting in national integration (18). Lack of understanding of the archipelago's insight can lead to the nation's disintegration (21). An understanding of the archipelago's insight can shape the nation's character as an asset in understanding Indonesia's geostrategy (16). The concept of geostrategy must also be understood by every citizen and then applied to the daily life of the Indonesian people to realize national resilience (17).

Insights on the archipelago are very important in being disseminated to young people to increase nationalism in the nation's successor. Education is considered the right medium in the socialization of the values of the archipelago's insight (13). Learning with the ProgramBased Learning Proven to be method effectively improves students' understanding of Indonesian insights (14). Learning Indonesian geography can also improve understanding of 
the concept of national geography, so that it will create unity to realize national resilience $(15)$.

\section{DISCUSSION}

\section{The Role of the Archipelago's Insight on the Indonesian Nation Indonesian}

Society is a multicultural society, in other words the Indonesian people can live in the diversity of cultures that exist in the living conditions of their people. Multiculturalism in the Indonesian nation is reflected in the motto "Bhinneka Tunggal Ika" which means unity among diversity (3). This diversity lies in the differences in ethnicity, religion, culture that exist among Indonesian people. This difference occurs due to several factors: 1) Geographical conditions, 2) Differences in climate, 3) Location of the region. These factors cause Indonesia to have cultural diversity to be called a multicultural country (2).

The condition of Indonesian society which consists of various cultures has earned Indonesia the nickname multicultural. It is known as a multicultural country, Indonesia is also a country multimental that is influenced by the cultures of many countries (3). This diversity can be a great potential in making the existence of the Indonesian state exist. Still, on the other hand it can also cause Indonesia to become a country prone to racial conflicts. Pancasila, which is the ideology of the Indonesian nation, can be an antidote to the threat of national disintegration (20). However, Pancasila also needs to be strengthened with the same perspective among citizens in Indonesia. Therefore, Indonesia needs to have a perspective in interpreting differences in Indonesia as a wealth that needs to be preserved.

The archipelago's insight is one way of looking at it in understanding the meaning contained in the national identity. The meaning contained in the insight of the archipelago upholds the value of unity and integrity in social life. The insight of archipelago needs to be understood by every Indonesian citizen in maintaining the Republic Republic's Indonesia. In addition, the environment that continues to move dynamically makes the position of archipelago insight very important in the existence of the Indonesian nation. (11).

From the explanation above, It can conclude that the insight of the archipelago plays an important role in guiding the life of the Indonesian people. The archipelago insight can be a way of shaping the character of the Indonesian nation (16). Socialization of the archipelago 
insight is very important to do so that people can get to know the Indonesian nation more deeply, so that they can instill a sense of love for the country in every Indonesian citizen $(21,22,14,19)$. Archipelago insight can also be a control, because the source from the insight of the archipelago also comes from Pancasila and the 1945 Constitution which are one of the guidelines for acting in social life. By interpreting the true insight of the archipelago, the multicultural situation in Indonesia is not a barrier to maintaining the integrity of the Republic of Indonesia (23).

\section{National Geostrategy in the life of the Indonesian nation}

Geostrategy is a concept that explains strategic conditions in the use of geographic conditions to overcome all threats and problems. Geostrategy does not only focus on the geographical conditions that exist in an area, but also absorbs the socio-cultural conditions of the people (24). Its role in understanding Indonesia's geographical conditions can be one way to increase love for the Indonesian homeland (15).

In the concept of Indonesia's geostrategy, seven things are of great concern, namely: 1) the demographic conditions of Indonesia, which number more than 200 million people, and the area flanked by two continents, 2) the Pancasila ideology is an ideology formed between the two biggest ideologies, namely communism and liberalism, 3) politics in the Indonesian state lies between the parliamentary democracy in the south and the proletarian dictatorial system in the north, 4) the economic principles that exist in Indonesia are between a liberal and centralized economy, 5) the socio-cultural situation in Indonesia is between individualism and communism, 6 ) Indonesian culture is in a position between western culture and eastern culture, 7) in defense and security, continental defense systems or land forces in the north and maritime defense systems in the west, south, and east (24).

Strategies for exploiting geographic conditions in the nation's life can be one way of realizing national goals. This utilization is implemented through a national geostrategy which can be one way to maintain national resilience. Therefore, geostrategy in Indonesian society is to strengthen national resilience through the use of geographical conditions in the territory of Indonesia (25).

\section{The Role of Archipelago Insights in National Geostrategy}

Multicultural education aiming to foster an attitude of tolerance in fostering 
differences in Indonesia is very important in fostering cultural diversity in Indonesia (26). The archipelago concept is a concept aimed at uniting different views in society to create national unity. the formation of national unity will also create national resilience (19). Therefore, national resilience must be built strongly in the life of the Indonesian people so that the national identity is not destroyed due to external threats that can divide the nation (27).

The concept of Archipelago Insights takes geographical conditions into account as a basis for building national resilience. Geostrategy in national resilience is also the ideal of the Indonesian nation as stated in the 1945 Constitution (17). Geostrategy is also an implementation of geopolitics applied in Indonesia, so that the direction and objectives of the utilization of Indonesia's geographical conditions are aimed at building national resilience (25). Therefore it is very important if the insight of the archipelago is used as a guide in building national resilience (17).

\section{CONCLUSION}

Archipelago insights and national geostrategy greatly influence national resilience. The concepts that exist in the archipelago and national geostrategy can foster the diversity that exists in Indonesia. The creation of existing unity and integrity and understanding the perception of seeing differences is not a threat to realizing national resilience in the Indonesian nation.

\section{REFERENCES}

1. Saputra TA. Bentuk Kecemasan Dan Resiliensi Mahasiswa Pascasarjana AcehYogyakarta Dalam Menghadapi Pandemi Covid-19. J Bimbing Dan Konseling ArRahman. 2020;6(1):55.

2. Mubit R. Peran Agama Dalam Multikulturalisme Masyarakat Indonesia. Epistemé J Pengemb Ilmu Keislam. 2016;11(1):163-84.

3. Lestari G. Bhinnekha Tunggal Ika: Khasanah Multikultural Indonesia di Tengah Kehidupan Sara. J Pendidik Pancasila dan Kewarganegaraan. 2015;28(1):31-7.

4. Sodik F. Pendidikan Toleransi Dan Relevansinya Dengan Dinamika Sosial Masyarakat Indonesia. Tsamratul Fikri. 2020;14(1):1-14.

5. Indrawan RMJ, Efriza E. Membangun Komponen Cadangan Berbasis Kemampuan Bela Negara Sebagai Kekuatan Pertahanan Indonesia Menghadapi Ancaman Nir-Militer. J Pertahanan Bela Negara. 2018;8(2):21-40.

6. Najmina N. Pendidikan Multikultural Dalam Membentuk Karakter Bangsa Indonesia. Jupiis J Pendidik Ilmu-Ilmu Sos. 2018;10(1):52. 
7. Program A, Angkatan P, Lviii P, Ri L. Meningkatkan Pemahaman Diaspora tentang Wawasan Nusantara sebagai Upaya untuk Menyukseskan Pemilihan Umum. J Kaji Lemhannas RI. 2019;7(1):5-14.

8. Setiawan D. Kontribusi Tingkat Pemahaman Konsepsi Wawasan Nusantara terhadap Sikap Nasionalisme dan Karakter Kebangsaan Deny. Jupiis J Pendidik Ilmu-Ilmu Sos. 2017;9(1):20.

9. Suradinata E. GEOPOLITIK DAN GEOSTRATEGI DALAM MEWUJUDKAN INTEGRITAS NEGARA KESATUAN REPUBLIK INDONESIA. J Ketahanan Nas. 2001;

10. Priyono J, Herman, Yusgiantoro P. Uji falsifikasi konsepsi ketahanan nasional sebagai geostrategi indonesia. J Pertahanan Bela Negara. 2017;7:115-30.

11. Calam A, Sobirin. Formulasi Geopolitik di Era Reformasi. J SAINTIKOM. 2009;7(2):350-65.

12. Habsy BA. Seni Memehami Penelitian Kuliatatif Dalam Bimbingan Dan Konseling: Studi Literatur. JURKAM J Konseling Andi Matappa. 2017;1(2):90.

13. Saputra I. Peran Organisasi Kepemudaan Dalam Meningkatkan Pemahaman Wawasan Nusantara Di Kalangan Pemuda Indonesia. J Ilmu Pendidik PKn dan Sos Budaya. 2017;1(1):33-41.

14. Tenis MA, Utami PP, Brahma IA. Upaya Meningkatkan Hasil Belajar Siswa pada Materi Wawasan Nusantara melalui Problem-Based Learning. 2020;(75):1-6.

15. Chaerunnisa H. Peran Geografi Dalam Menanamkan Rasa Cinta Tanah Air Dan Wawasan Nusantara Di Sman 1 Pagaden. Peran Geogr Dalam Menanamkan Rasa Cinta Tanah Air Dan Wawasan Nusant Di Sman 1 Pagaden. 2019;19(1):76-83.

16. Mulya L. Postur Maritim Indonesia : Pengukuran Melalui Teori Mahan. J Lembaran Sej. 2013;10(2):128-34.

17. Syam HD. Manifestasi integritas nkri dalam geostrategi dan ketahanan nasional. 2020.

18. Soemaatmadja R, Supriatna $\mathrm{T}$, Rowa H. Ideal Model in the Implementation of National Insight Policies for Handling Social Conflict in Pandeglang Regency. Int J Sci Soc. 2020;2(4):253-65.

19. Gumuruh AR, Adinata TP. IMPLEMENTATION OF ARCHIPELAGO INSIGHTS IN NATIONAL INTEGRATION. Santhet (Jurnal Sejarah, Pendidikan, dan Humaniora). 2020;4(1):10-8.

20. Aulia R, Sugito N. Implementation of Pancasila in Developing National Insights During the COVID-19 Pandemic. Adv Soc Sci Educ Humanit Res. 2021;524(Icce 2020):201-7.

21. Hasanah I, Dzikrika N. KAJIAN WAWASAN KEBANGSAAN DAN PARTISIPASI POLITIK MASYARAKAT PERBATASAN TEMAJUK. J Cendekia Sambas. 2020;1:39-49.

22. Saputra I. Peran Organisasi Kepemudaan Dalam Meningkatkan Pemahaman Wawasan Nusantara Di Kalangan Pemuda Indonesia. J Ilmu Pendidik PKn dan Sos Budaya. 2019;9924:33-41.

23. Aminullah, Rodi dan Umam M. Pancasila sebagai wawasan nusantara. Al-Allam [Internet]. 2020;1, no 1:1-16. Available from: http://ejournal.kopertais4.or.id/madura/index.php/alallam/article/download/4076/2978

24. Rahman F. Implementasi Doktrin Tridarma Ekakarma Melalui Teori Perimbangan Kekuatan. J Sos Polit. 2018;4(1):78.

25. Priyono J, Herman H, Yusgiantoro P. Falsification Test of The National Resilience Concept as Indonesian Geostrategic Doctrine. J Pertahanan. 2017;3(2):123.

26. Najmina N. Pendidikan Multikultural Dalam Membentuk Karakter Bangsa Indonesia. 
J Pendidik Ilmu-Ilmu Sos. 2018;10(1):52-6.

27. Soepandji KW, Farid M. Konsep Bela Negara Dalam Perspektif Ketahanan Nasional. J Huk Pembang. 2018;48(3):436.

Table 1

Tabel 1. Literature Result

\begin{tabular}{|c|c|c|c|c|}
\hline & Methods & Results & Conclusion & Population \\
\hline $\begin{array}{l}\text { (Hasana } \\
\text { h and } \\
\text { Dzikrika } \\
, 2020\end{array}$ & Qualitative. & $\begin{array}{l}\text { People in the village Temajuk } \\
92 \% \text { of respondents revealed } \\
\text { that the needed extension and } \\
8 \% \text { of respondents said the } \\
\text { extension is necessary to } \\
\text { instill the concept of } \\
\text { nationalism such as the } \\
\text { planting of nationalism and a } \\
\text { sense of patriotism in people's } \\
\text { self to increase the love of the } \\
\text { homeland }\end{array}$ & $\begin{array}{l}\text { Stay in the border area } \\
\text { are not made public } \\
\text { Temajuk shut } \\
\text { themselves in the } \\
\text { outside world and } \\
\text { understand the meaning } \\
\text { of the concept of } \\
\text { nationalism itself. } \\
\text { Knowing his lack of } \\
\text { understanding of the } \\
\text { concept of nationalism } \\
\text { can lead to } \\
\text { disintegration. }\end{array}$ & $\begin{array}{l}\text { villagers of } \\
\text { Temajuk } \\
\text { especially in } \\
\text { Dusun Maludin } \\
\text { with } 272 \text { heads } \\
\text { of families } \\
\text { consisting of } 995 \\
\text { people }\end{array}$ \\
\hline $\begin{array}{l}\text { (Saputra } \\
\text {, 2017) }\end{array}$ & Qualitative & $\begin{array}{l}\text { Youth organization can carry } \\
\text { out the role of youth } \\
\text { organizations in } \\
\text { understanding, appreciating, } \\
\text { and practicing the } \\
\text { archipelago's insights in social } \\
\text { life effectively through } \\
\text { education and local cultural } \\
\text { development. The world of } \\
\text { education is seen as an } \\
\text { effective means of } \\
\text { transferring knowledge of the } \\
\text { archipelago's insights and real } \\
\text { practice. }\end{array}$ & $\begin{array}{l}\text { Understanding the } \\
\text { insight of the } \\
\text { archipelago has an } \\
\text { impact on increasing } \\
\text { nationalism so that } \\
\text { every Indonesian citizen } \\
\text { will increasingly love } \\
\text { their homeland. By } \\
\text { getting knowledge of } \\
\text { the archipelago, } \\
\text { Indonesian people will } \\
\text { also have awareness } \\
\text { about themselves and } \\
\text { their strategic } \\
\text { environment to increase } \\
\text { their awareness of all } \\
\text { disturbances } \\
\text { threaten the stability of } \\
\text { their nation. . }\end{array}$ & - \\
\hline $\begin{array}{l}\text { (Priyon } \\
\text { o et al., } \\
2017 \text { ) }\end{array}$ & Qualitative. & $\begin{array}{l}\text { the conception of National } \\
\text { Resilience outside the } \\
\text { periphery of geostrategy, } \\
\text { although evidence is found to } \\
\text { indicate the applicability of } \\
\text { geostrategy. }\end{array}$ & $\begin{array}{l}\text { the conception of } \\
\text { National Resilience } \\
\text { outside the periphery of } \\
\text { geostrategy, evidence is } \\
\text { found showing the } \\
\text { applicability of }\end{array}$ & \\
\hline
\end{tabular}


showing the non-validity of geostrategy and geostrategy: (1) it does not Evidence that shows the place an emphasis on applicability of (military) strategy; (2) does geostrategy not indicate strategic in the conception planning, political / ofResilience diplomatic efforts, or military National efforts; (3) not actively influencing regional politicsstrategy; (4) changes occur over a long period; and (5) defense prioritizes an attitude of consultation and cooperation. Evidence showing the applicability of geostrategy: (1) formulating National Goals; and (2) considering geographic and geopolitical conditions and constellations.

(Tennis classroom The findings of his research PBL learning methods Interviews were et al., action that PBL learning has a can improve student conducted with 2020) research. In positive impact in improving PPKn learning students and this student learning outcomes outcomes, especially in teachers of class research, because it is marked by an the material insight into X IPS 3 at SMA there are increase in student learning the archipelago; Negeri 1 Setu four stages completeness in each cycle, for each namely pre-cycle $(28.12 \%)$ cycle. $\quad$ cycle I $(40 \%)$, cycle II $(65 \%)$, cycle III $(81.25 \%)$. Thus, PBL learning improves student learning outcomes, especially in the Archipelago Insights material.

\begin{tabular}{|c|c|c|c|c|}
\hline $\begin{array}{l}\text { (Chaeru } \\
\text { nnisa, } \\
2019 \text { ) }\end{array}$ & $\begin{array}{l}\text { Qualitative } \\
\text { and } \\
\text { Quantitative }\end{array}$ & $\begin{array}{l}\text { This research obtained a good } \\
\text { result in increasing love for } \\
\text { the country, good insight into } \\
\text { the archipelago, and } \\
\text { increasing confidence in God } \\
\text { Almighty. through geography } \\
\text { education with a learning } \\
\text { cycle approach at Pagaden } 1\end{array}$ & $\begin{array}{l}\text { from the graph that } \\
\text { states the role of } \\
\text { geography can increase } \\
\text { the love of the country } \\
\text { shows a perfect number, } \\
\text { namely } 100 \% \text { of }\end{array}$ & $\begin{array}{lr}\text { students } & \text { at } \\
\text { SMAN } & 1 \\
\text { Pagaden using a } \\
\text { random sample } \\
\text { and making all } \\
\text { XI IPS } \\
\text { students as } \\
\text { objects }\end{array}$ \\
\hline
\end{tabular}
Public Senior High School. 


\begin{tabular}{|c|c|c|c|c|}
\hline $\begin{array}{l}\text { (Mulya, } \\
\text { 2013) }\end{array}$ & Qualitative & $\begin{array}{l}\text { Viewing Indonesia using } \\
\text { Mackinder's criticism against } \\
\text { Mahan, can help balance sea } \\
\text { and land forces. Both as a } \\
\text { threat and an opportunity, the } \\
\text { position of the sea remains } \\
\text { unchanged from the main } \\
\text { position, namely protection } \\
\text { for the center of politics, } \\
\text { economy, and population on } \\
\text { land. For this reason, the } \\
\text { geostrategic concept of an } \\
\text { archipelagic state is still } \\
\text { considered relevant because } \\
\text { of the withdrawal of territorial } \\
\text { boundaries from archipelagic. }\end{array}$ & $\begin{array}{l}\text { re-examination of the } \\
\text { archipelago's insights } \\
\text { can be a means of } \\
\text { shaping a national } \\
\text { character. In the end, } \\
\text { factual awareness and } \\
\text { openness to change are } \\
\text { provisions for } \\
\text { understanding } \\
\text { geostrategy }\end{array}$ & - \\
\hline $\begin{array}{l}\text { (Syam, } \\
2020)\end{array}$ & Qualitative & $\begin{array}{l}\text { understanding of geostrategy } \\
\text { and national resilience in this } \\
\text { research concerns the } \\
\text { realization of the ideals of the } \\
\text { proclamation, as stated in the } \\
\text { Preamble to the } 1945 \\
\text { Constitution, namely } \\
\text { protecting the entire } \\
\text { Indonesian nation and all } \\
\text { Indonesian blood, advancing } \\
\text { public welfare, educating the } \\
\text { nation's life, and participate in } \\
\text { implementing world order }\end{array}$ & $\begin{array}{l}\text { It is the obligation of all } \\
\text { children of the nation, } \\
\text { especially state } \\
\text { administrators, to } \\
\text { understand and } \\
\text { actualize geostrategy in } \\
\text { the administration of } \\
\text { national life and } \\
\text { national development to } \\
\text { create independent } \\
\text { national resilience. }\end{array}$ & - \\
\hline $\begin{array}{l}\text { (So } \\
\text { Jamama } \\
\text { dja et } \\
\text { al., } \\
2020)\end{array}$ & Qualitative & $\begin{array}{l}\text { The study results found that } \\
\text { several factors influenced the } \\
\text { implementation of the } \\
\text { national insight policy such as } \\
\text { the insufficient capability of } \\
\text { the national insight education } \\
\text { center team, low community } \\
\text { participation, limited budget. }\end{array}$ & $\begin{array}{l}\text { Several factors hinder } \\
\text { the implementation } \\
\text { process of the National } \\
\text { Insights Policy in } \\
\text { Pandeglang Regency, } \\
\text { including: } \\
\text { Capability of the } \\
\text { National Insights } \\
\text { Education Center Team } \\
\text { is Not Appropriate, } \\
\text { Community } \\
\text { Participation is still low, } \\
\text { Budget Limitations for } \\
\text { the Implementation of }\end{array}$ & - \\
\hline
\end{tabular}


National Insights

Education. All of these

factors illustrate the influence both from internal government and external from the government, which hinders implementing a collaborative national insight policy.

\begin{tabular}{|c|c|c|c|c|}
\hline $\begin{array}{l}\text { (Gumur } \\
\text { uh and } \\
\text { Adinata, } \\
2020 \text { ) }\end{array}$ & Qualitative & $\begin{array}{l}\text { values of the insight of the } \\
\text { archipelago, especially the } \\
\text { value of unity, namely the } \\
\text { unity of IPOLEKSOSBUD- } \\
\text { HANKAM strongly supports } \\
\text { national integration. }\end{array}$ & $\begin{array}{l}\text { The fostering and } \\
\text { dissemination of the } \\
\text { Archipelago insight is } \\
\text { very important for the } \\
\text { nation state because it } \\
\text { can produce National } \\
\text { Resilience. Strong } \\
\text { endurance for a nation } \\
\text { and synergistic } \\
\text { cooperation between } \\
\text { fields } \\
\text { (IPOLEKSOSBUD- } \\
\text { HANKAM) which are } \\
\text { continuously pursued } \\
\text { can produce a complete } \\
\text { and comprehensive } \\
\text { national integration }\end{array}$ & - \\
\hline $\begin{array}{l}\text { (Aulia } \\
\text { and } \\
\text { Sugito, } \\
2021 \text { ) }\end{array}$ & Qualitative & $\begin{array}{l}\text { Pancasila is expected to } \\
\text { internalize and inspire us as } \\
\text { citizens to stay united during } \\
\text { the COVID-19 pandemic like } \\
\text { today, such as sharing hand } \\
\text { sanitizers, masks and our } \\
\text { excess staples, so that The } \\
\text { sustainability will always } \\
\text { maintain the sustainability of } \\
\text { the insight into the Indonesian } \\
\text { nation following the problems } \\
\text { and demands of every age }\end{array}$ & $\begin{array}{l}\text { Through the } \\
\text { implementation of the } \\
\text { principles in Pancasila } \\
\text { which will synergize the } \\
\text { centralized strength of } \\
\text { the Pancasila values } \\
\text { (centripetal) and the } \\
\text { strength of the elements } \\
\text { of real behavior that } \\
\text { spread (centrifugal), } \\
\text { Pancasila can provide } \\
\text { solutions to every } \\
\text { problem faced by } \\
\text { Indonesia. Pancasila is } \\
\text { expected to be able to } \\
\text { Advances in Social } \\
\text { Science, Education and } \\
\text { Humanities Research, }\end{array}$ & - \\
\hline
\end{tabular}


volume 524205

internalize society with

its noble values during

the

COVID-19

pandemic. 